\title{
Process and Product Design: Production Efficiency of Manufacturing Firms in Rivers State, Nigeria
}

\author{
Karibo B. Bagshaw ${ }^{1}$ \\ ${ }^{1}$ Department of Management, Rivers State University of Science and Technology, Port Harcourt, Nigeria \\ Correspondence: Karibo B. Bagshaw, Department of Management, Rivers State University of Science and \\ Technology, P.M.B. 5080, Port Harcourt, Nigeria. Email: bagshaw.karibo@ust.edu.ng
}

Received: December 12, 2016

Accepted: December 23, 2016

Online Published: March 20, 2017

doi:10.5539/emr.v6n1p49

URL: http://doi.org/10.5539/emr.v6n1p49

\begin{abstract}
Manufacturing firms employ structured approach to ensure that its production system is designed to achieve the firm's business objectives. The study examined the influence of process and product design on production efficiency of 28 manufacturing firms listed with Manufacturers' Association of Nigeria. Structured questionnaire was administered and analyzed using percentages, mean, regression analysis and t-statistic in testing the hypothesis. The findings showed that process design and product design has a significant positive influence on production efficiency. Therefore, the study recommend that manufacturing firms in Nigeria should pay attention to the issues of product design regularly; keeping in mind future growth, expansion plans, market trend and future demands; and that improved methods and processes should be adopted in accomplishing a given task.
\end{abstract}

Keywords: process design, product design, production efficiency

\section{Introduction}

The task in any productive endeavour is the process and product design, which extends from the design of operations to decisions on how to accomplish task or work assignments. In creating a new product or service, the key issue to be considered is the design. Every outstanding design translates customers wants and needs to tangible products, increases quality, refine existing products or services, set cost targets and translate products and service specification into process specifications (Baldwin \& Clark, 2010; Gorman, 2012).

It provides relevant information on such important questions as vital characteristics of the product, types of machines, equipment and tools, the expected volume of output and types of labour skill required to enhance the efficiency of production. Answer to these questions would serve as necessary inputs for process design efforts (Bellgram, Gullander, \& Harlin, 2010).

Hayes, Pisano, David, Upton and Wheelwright (2012) in their study on process design revealed that process design coordinates the mix of machines, tools and materials in the production process.

Alix and Vallespir (2009) stated that the overall objective of the process and product design is to improve product quality in satisfying customers' expectation. It is important to note that although organizations have to maximise profit, the time difference between the design phase and the actual production takes a considerably long time, thereby increasing cost. Thus the overall measure of design effectiveness should take into considerations the element of product quality as an overriding objective.

Cohen and Uday (2008) stated that organizations get involved in design in other to increase productivity minimize customers complaint, excessive warranty claims and product return rate.

To be sustained in the global scenario, organizations' focus is to design a production system that can fulfil all the demand orders within due dates at a reasonable cost (Malhotra, 2008). Design decisions have strategic importance for business organizations. Hence managers are becoming more interested in the design process in other to remain competitive.

\section{Literature Review}

Manufacturing organizations are set up to convert input resources through the transformation process in workstations to get product output and achieve profit maximization as well as running efficient production process. Hawker and Chris (2010) observed that designing a system for optimum efficiency and productivity 
requires overlapping perspectives: process, task, product, and the organization itself. On the other hand, Ulrich and Steven (2009) noted that, the challenge for manufacturers is to propose a design that supports their firm's core competencies (flexibility and quality) while considering all the dimensions of the design and analysing their interdependence in relation to value creation of the firm.

Hayes and Pisano (2011) noted that manufacturing organizations in their bid to improve their competitiveness implements programmes such as lean manufacturing, just in time production process and quality management. However, it was observed that they don't always achieve the intended results due to the generic nature of the approaches they adopt, more so, designing production and operation systems involves equipment selection, physically arranging the equipment and machines in the job floor.

Again, Madu, Kuei, and Lin (2010), in their study of manufacturing efficiency observed that, systems designers select among the available and identified options that best suit the requirements that have been specified. The production system is achieved as a result of implementing the ideas that are created and specified in the systems design process. Also, Schmenner (2009) observed that during product design, the processes must be planned, more so in planning the process, the general features of the part, such as the material, surface finish, configuration, and tolerances level, must be first determined. These features will shape the type of tools and machines, part handling, assembly line and the sequence of operations.

The determination of the physical features during the product design phase will help control the quality of the product rendered to the consumers. Other aspects are also affected by what happens during the design process, such as, the time it takes to design and build the production system which in turn controls when production ultimately starts, the total time it takes to market the product, and the relevant cost implications.

Morris (2009) stated that product design impacts every functional area of an organization. Thus, operations and marketing should be involved because sufficient information must be generated to clearly determine customer wants. This must be conveyed to those responsible for designing, marketing and producing a particular product or service. Furthermore, Pullman and William (2011) stated that the market demand for a product and its uses must be clearly determined during the process design with data from sales personnel, marketing manager and others decision makers within the organization. Shaw (2010) observed that businesses are now taking into account legal and environmental concerns when designing new product or service.

More so, one of the major reasons for product or service development is to provide satisfaction for basic needs of customers. Therefore, product must be design in such a way that it will provide the necessary satisfaction for the customers in cost efficient way (Bagshaw, 2015).

\section{Research Methodology}

A survey design was adopted, with 36 manufacturing firms listed with the Manufacturers' Association of Nigeria (MAN) in Rivers State as the population of the study. The sample size is 33 manufacturing firms based on Krejece and Morgan (1970) Table for sample size determination. 28 completed copies of the distributed questionnaire were retrieved and used as sample size in the presentation and analysis of data.

The model below was specified in line with the hypotheses. The specified model expresses the relationship between the criterion variable (production efficiency) and the predictor variable (process design/product Design).

$$
\begin{aligned}
& \mathrm{Y}=\mathrm{f}\left(\mathrm{x}_{1}, \mathrm{x}_{2}\right)-----(1 \mathrm{a}) \\
& \text { Rewriting (1a) explicitly } \\
& \mathrm{Y}=\mathrm{a}_{0}+\mathrm{a}_{1} \mathrm{x}_{1}+\mathrm{a}_{2} \mathrm{x}_{2}+\mathrm{u}_{1} \ldots \ldots . .(1 \mathrm{~b}) \\
& \mathrm{PE}=\mathrm{a}_{0}+\mathrm{a}_{1} \mathrm{PDD}+\mathrm{a}_{2} \mathrm{PCD}+\mathrm{U}_{1}
\end{aligned}
$$

\section{Data Analysis and Discussion}

The discussion on the findings is on process design and product design in relation to production efficiency.

\subsection{Process Design and Production Efficiency}

An organization is only as efficient and effective as its processes; the process of designing a product first requires an understanding of the functionality and performance expected from the product (Kingman-Brundage, 2010).

Chaiken (2007) stated that process design is the organization of resources in a facility in other to enhance the production process. If resources are not properly arranged, manufacturing firms will suffer inefficiency thereby leading to waste and loss of productivity. Thus, to what extent does process design influence production efficiency? 
The presentation of data is in Table 1 .

Table 1. Items and scores on response of process design

\begin{tabular}{|c|c|c|c|c|c|c|c|c|}
\hline $\mathrm{S} / \mathrm{n}$ & Questionnaire Items & Very great/great & Undecided & Very low/low & $\mathrm{f}$ & fx & Mean & Remark \\
\hline 1 & $\begin{array}{l}\text { Does the process design adopted } \\
\text { by your firm reduce the amount } \\
\text { of time it takes to be done? }\end{array}$ & $\begin{array}{c}24(85.7 \%) \\
(72)\end{array}$ & $\begin{array}{c}1(3.6 \%) \\
(2)\end{array}$ & $\begin{array}{c}3(10.7 \%) \\
(3)\end{array}$ & $\begin{array}{c}28 \\
(100 \%)\end{array}$ & (77) & 2.75 & $\begin{array}{l}\text { Great } \\
\text { Extent }\end{array}$ \\
\hline 2 & $\begin{array}{l}\text { In our firm, we have new and } \\
\text { improved ways as well as } \\
\text { techniques }\end{array}$ & $\begin{array}{c}20(71.4 \%) \\
60\end{array}$ & $\begin{array}{c}3(10.7 \%) \\
(6)\end{array}$ & $\begin{array}{c}5(17.9 \%) \\
5\end{array}$ & $\begin{array}{c}28 \\
(100 \%)\end{array}$ & (71) & 2.54 & Moderate \\
\hline
\end{tabular}

Source: Survey 2016.

From Table 1 above, $85.71 \%$ of the respondents agreed that process design adopted reduced the amount of time it takes for a task to be completed, while $71.43 \%$ of the respondent agreed that new and improved techniques in processing their task influenced their production efficiency.

The unique features of a product and the configuration of the machines and equipment whether general or special purpose would enable the process designer to decide on the appropriateness of either the continuous or intermittent production system (Almgren, 2011).

According to Malhotra (2008) posited that Operations managers should consider the capital intensity and flexibility of the process before adopting it, noting that the greater the relative cost of equipment, the greater the capital intensity. Hence operations managers should pay more attention to process design as a poor process design will impinge on the efficiency of their firms.

In the final analysis, Harris and Gonzales (2009) observed that, choosing the best alternative process design is in most cases determined by the characteristics of the product, demand levels and cost of the production process can accommodate considering the stability of the process design.

\subsection{Product Design and Production Efficiency}

Product design commences with spawning of product ideas, which are further examined and every aspect properly identified, considering the technical requirements of each product, in line with availability of skilled personnel and machines (Slack, Chambers, \& Johnston, 2010).

Product design relates to functions, cost, quality, appearance and forecasted volume, ease of production, assembly, maintenance or service. Chambers (2011) observed that an organization that fails to take these into consideration can result to low efficiency, low quality and increased cost. Thus, to what extent does product design influence production efficiency?

The presentation of data is in Table 2 .

Table 2. Items and scores on response on product design

\begin{tabular}{|c|c|c|c|c|c|c|c|c|}
\hline $\mathrm{S} / \mathrm{n}$ & Questionnaire Items & $\begin{array}{c}\text { Very } \\
\text { great/great }\end{array}$ & Undecided & $\begin{array}{c}\text { Very } \\
\text { low/low }\end{array}$ & $\mathrm{f}$ & fx & Mean & Remark \\
\hline 1 & $\begin{array}{l}\text { In our firm, we often redesign our } \\
\text { product }\end{array}$ & $\begin{array}{c}21(75.0 \%) \\
(63)\end{array}$ & $\begin{array}{c}2(7.7 \%) \\
(4)\end{array}$ & $\begin{array}{c}5(17.9 \%) \\
(5)\end{array}$ & $\begin{array}{c}28 \\
(100 \%)\end{array}$ & $(72)$ & 2.57 & Moderate \\
\hline 2 & $\begin{array}{l}\text { Our existing products often undergo } \\
\text { improvement }\end{array}$ & $\begin{array}{c}20(71.4 \%) \\
60\end{array}$ & $\begin{array}{c}2(7.1 \%) \\
(4)\end{array}$ & $\begin{array}{c}6(17.9 \%) \\
(6)\end{array}$ & $\begin{array}{c}28 \\
(100 \%)\end{array}$ & $(70)$ & 2.50 & Moderate \\
\hline 3 & $\begin{array}{l}\text { The product design agrees, with the } \\
\text { system design adopted by our firm }\end{array}$ & $\begin{array}{l}24(85.7 \%) \\
72\end{array}$ & $\begin{array}{c}0(0.0 \%) \\
(0)\end{array}$ & $\begin{array}{c}4(14.3 \%) \\
(4)\end{array}$ & $\begin{array}{c}28 \\
(100 \%)\end{array}$ & (76) & 2.71 & $\begin{array}{l}\text { Great } \\
\text { Extent }\end{array}$ \\
\hline
\end{tabular}

Source: Survey 2016. 
From Table 2 above; $75 \%$ of the respondents accepted that redesigning a product or service influences the production efficiency of their firms. Also, $71.43 \%$ accepted that improvement on services or product delivered influenced the efficiency of their firms. Again $85.71 \%$ agreed that the product design adopted affected the efficiency of their firms.

Ternicko (2011) pointed out that products undergo a life cycle in terms of demand and relevance. When a product is introduced it may be treated with curiosity, with the passage of time it is expected that product design should enhance lead time reduction (that is the amount of time it takes for customers order to be met) thereby leading to optimum efficiency.

The objective of a design either of product or service is to appease customers by meeting their needs and expectations without compromising quality. This will enhance the efficiency and competitive position of the organization; hence product design is seen as starting and ending with efficiency (Davis \& Janelle, 2009). Therefore manufacturers should pay a closer attention to their product design in order to enhance the efficiency of their firms.

\subsection{Influence of Process Design (PCD) and Product Design (PDD) on Production Efficiency (PE)}

Table 3. Items and scores on response on production efficiency

\begin{tabular}{|c|c|c|c|c|c|c|c|c|}
\hline $\mathrm{S} / \mathrm{n}$ & Questionnaire Items & $\begin{array}{c}\text { Very } \\
\text { great/great }\end{array}$ & Undecided & $\begin{array}{c}\text { Very } \\
\text { low/low }\end{array}$ & $\mathrm{f}$ & fx & Mean & Remark \\
\hline 1 & $\begin{array}{l}\text { What is your ratings of your current } \\
\text { level of production efficiency }\end{array}$ & $\begin{array}{c}25(89.3 \%) \\
(75)\end{array}$ & $\begin{array}{c}3(10.7 \%) \\
(6)\end{array}$ & $\begin{array}{c}0(0.0 \%) \\
(0)\end{array}$ & $\begin{array}{c}28 \\
(100 \%)\end{array}$ & $(81)$ & 2.89 & $\begin{array}{l}\text { Great } \\
\text { Extent }\end{array}$ \\
\hline 2 & $\begin{array}{l}\text { Product design is influential in the } \\
\text { current level of production efficiency }\end{array}$ & $\begin{array}{c}24(85.7 \%) \\
72\end{array}$ & $\begin{array}{c}4(7.1 \%) \\
(4)\end{array}$ & $\begin{array}{c}0(0.0 \%) \\
(0)\end{array}$ & $\begin{array}{c}28 \\
(100 \%)\end{array}$ & (76) & 2.71 & $\begin{array}{l}\text { Great } \\
\text { Extent }\end{array}$ \\
\hline 3 & $\begin{array}{l}\text { Process design is influential in the } \\
\text { current level of production efficiency }\end{array}$ & $\begin{array}{c}22(78.6 \%) \\
66\end{array}$ & $\begin{array}{c}6(21.4 \%) \\
(12)\end{array}$ & $\begin{array}{c}0(0.0 \%) \\
(0)\end{array}$ & $\begin{array}{c}28 \\
(100 \%)\end{array}$ & $(78)$ & 2.79 & $\begin{array}{l}\text { Great } \\
\text { Extent }\end{array}$ \\
\hline
\end{tabular}

Source: Survey 2016.

Table 4. Summary of regression analysis showing the influence of Process Design (PCD) and Product Design (PDD) on Production Efficiency (PE)

\begin{tabular}{cccccccccc}
\hline Variables & Coef. & t-cal & sig. & t-tab $(0.05,27)$ & $\mathrm{R}$ & $\mathrm{R}^{2}$ & F-cal & F-tab $(0.05,2,25)$ & sig f \\
\hline Constant & 0.216 & 0.989 & 0.326 & & & & & & \\
PCD & 0.366 & 3.899 & 0.000 & 2.05 & 0.824 & 0.680 & 68.9 & 3.07 \\
PDD & 0.544 & 5.559 & 0.000 & & & & & & \\
\hline
\end{tabular}

Dependent Variable; Production Efficiency.

Source: SPSS 22.0 Output (based on field survey data 2016) Detail in Appendix.

Table 4 above showed that the correlation coefficient is 0.824 . This implies that a very strong correlation exist between the explanatory variable and the dependent variable (Correlation coefficient $r$ is closer to 1). The coefficient of Determination $\left(\mathrm{R}^{2}\right)=0.680$, this implies that $68 \%$ variation in Production efficiency is explained by variations in Process design and Product design. This is an indication that the model has a good fit. The remaining $32 \%$ is explained by other variables not included in the model. The F-calculated of 68.9 had a corresponding significant f-value of 0.000 ; the researcher therefore concludes a good model utility. Conventionally $\mathrm{F}-\mathrm{Cal}=68.9>\mathrm{F}-\mathrm{tab}_{(0.05,2,25)}=3.07$; hence the decision of a good model utility upheld.

$$
\begin{aligned}
& \mathrm{PE}=\mathrm{a}_{\mathrm{o}}+\mathrm{a}_{1} \mathrm{PCD}+\mathrm{a}_{2} \mathrm{PDD}+\mathrm{U}_{1} \\
& \mathrm{PE}=0.216+0.366 \mathrm{PCD}+0.544 \mathrm{PDD}
\end{aligned}
$$

t-values in bracket

$$
\text { (0.989) (3.899) }
$$




\section{Test of Hypotheses}

$\mathbf{H}_{\mathbf{O} 1}$ : Process design does not significantly influence production efficiency

The test of significance conducted as shown in Table 4 above shows that; Process design had $(\mathrm{PV}=0.000<0.05)$. More so, $\mathrm{t}-\mathrm{cal}=5.559>\mathrm{t}-\mathrm{tab}_{(0.05,27)}=2.05$; hence the null hypothesis is rejected and it is consequently concluded that Process design significantly influence Production efficiency.

$\mathbf{H}_{\mathbf{O} 2}$ : Product design does not significantly influence production efficiency

Table 4 also showed that; Product design had $(\mathrm{PV}=0.000<0.05)$. More so, $\mathrm{t}$-cal $=3.899>\mathrm{t}$-tab ${ }_{(0.05,27)}=2.05$; hence the null hypothesis is rejected and it is consequently concluded that Product design significantly influence Production efficiency.

\section{Conclusions}

Process and product design is of utmost importance to manufacturer as it gives them competitive edge over their counterpart. The challenge for manufacturers is to propose designs that support their firm's competence and analyze how they are interlinked with production efficiency and allowed for coherent value adding solution. More so, one of the major reasons for product or service development is to provide satisfaction for basic needs of customers, therefore, Production managers should take into account legal and environmental concerns when designing new product/service. Also, the design process should be included in the organization's strategy taking into cognisance other factors that affect the competences of the organization such as economic trends, technological changes, demographic changes and competitive markets.

\section{References}

Alix, T., \& Vallespir, B. (2009). New product development: Material versus immaterial. In Proc of Extended Product and Process Analysis and Design expand workshop.

Almgren, H. (2011). Pilot production and manufacturing start-up in the automotive industry principles for improved performance (Doctoral Thesis). Department of Operations, Chalmers University of Technology, Gothenburg.

Bagshaw, K. B. (2015). Assessing the capacity strategic options on capacity utilization of manufacturing firms in Rivers State, Nigeria. International Journal of Business and Social Science, 6(10), 67-79.

Baldwin, C. C., \& Clark, K. B. (2010). Managing in the age of Modularity. Harvard Business Review, 7(6), 84-93.

Bellgram, M., Gullander, P., \& Harlin, U. (2010). Towards improvement of production efficiency and effectiveness from a life-cycle perspective. Symposium on Robotics, Stockholm, Sweden.

Chaiken, S. (2007). Heuristic versus systematic information processing and the use of source versus message cues in persuasion. Journal of Personality and Social Psychology, 39(2), 752-769.

Chambers, O. (2011). Operation management (5th ed.). London: Prentice Hall.

Cohen, M. A., \& Uday, M. A. (2008). Manufacturing automation. New York: McGraw-Hill.

Davis, M., \& Janelle, H. (2009). Managing services: Using technology to create value. New York: McGraw-Hill/Irwin.

Gorman, H. A. (2012). The design of designs: A retrospective review. Journal of manufacturing technology, 7(4), $34-45$.

Harris, H. D., \& Gonzales, R. F. (2009). The operations, management: Role, problems and techniques. London, St. Paul: West publishing company.

Hawker, R., \& Chris, U. (2010). The inventor's mind: 10 steps to making money from inventions. Columbus: Trident Design.

Hayes, R. H., \& Pisano, G. P. (2011). Beyond world class: The new manufacturing Strategy. Harvard Business Review, 72(1), 43-57.

Hayes, R. H., Pisano, G. P., David, M., Upton, S., \& Wheelwright, C. (2012). Restoring our competitive edge. London: John Wiley.

Kingman-Brundage, J. (2010). Technology, design, and service quality. International Journal of Service Industry Management, 2(3), 47-57. https://doi.org/10.1108/EUM0000000002806 
Krejcie, R. V., \& Morgan, D. W. (1970). Determining sample size for research activities. Educational and Psychological Measurement, 30, 607-610. https://doi.org/10.1177/001316447003000308

Madu, C., Kuei, C., \& Lin, C. (2010). A comparative analysis of quality in manufacturing firms in the US and Taiwan. Decision Sciences, 26(5), 78-90.

Malhotra, M. K. (2008). A theoretical framework for analyzing the dimension of manufacturing flexibility. Journal of Operations Management, 18(20), 75-93.

Morris, R. (2009). The fundamentals of product design. New York: Mukugamu and Brothers Enterprises.

Pullman, M. E., \& William, L. M. (2011). Optimal service design: Integrating marketing and operations perspectives. International Journal of Service, Industry Management, 10(2), 239-260. https://doi.org/10.1108/09564239910264361

Schmenner, R. W. (2009). Manufacturing service and their integration: Some history and theory. International Journal of Operation and Production Management, 29(5), 431-443. https://doi.org/10.1108/01443570910953577

Shaw, J. C. (2010). The service focus. Burr: Rider lrwin.

Slack, N., Chambers, S., \& Johnston, R. (2010). Administration of Production. Sao Paulo: Atlas.

Ternicko, J. (2011). Step-by-step QFD: Customer driven product design (2nd ed.). Boca Raton, FL: CRC Press.

Ulrich, K., \& Steven, D. (2009). Product design and development (2nd ed.). London: McGraw-Hill.

\section{Appendixes}

Appendix 1. Variables Entered/Removed ${ }^{\mathrm{a}}$

\begin{tabular}{cccc}
\hline Model & Variables Entered & Variables Removed & Method \\
\hline 1 & Product Design, Process Design $^{\mathrm{b}}$ &. & Enter
\end{tabular}

a. Dependent variable: production efficiency.

b. All requested variables entered.

Appendix 2. Model summary

\begin{tabular}{ccccc}
\hline Model & $\mathrm{R}$ & R Square & Adjusted R Square & Std. Error of the Estimate \\
\hline 1 & $.824^{\mathrm{a}}$ & .680 & .670 & .69069
\end{tabular}

a. Predictors: (constant), product design, process design.

Appendix 3. ANOVA ${ }^{\mathrm{a}}$

\begin{tabular}{ccccccc}
\hline \multicolumn{2}{c}{ Model } & Sum of Squares & df & Mean Square & F & Sig. \\
\hline \multirow{3}{*}{1} & Regression & 65.756 & 2 & 32.878 & 68.919 & $.000^{\mathrm{b}}$ \\
& Residual & 11.925 & 25 & .477 & & \\
& Total & 77.681 & 27 & & & \\
\hline
\end{tabular}

a. Dependent variable: production efficiency.

b. Predictors: (constant), product design, process design. 
Appendix 4. Coefficients ${ }^{\mathrm{a}}$

\begin{tabular}{|c|c|c|c|c|c|c|}
\hline & \multirow[t]{2}{*}{ Model } & \multicolumn{2}{|c|}{ Unstandardized Coefficients } & \multirow{2}{*}{$\begin{array}{c}\text { Standardized } \\
\text { Coefficients }\end{array}$} & \multirow[t]{2}{*}{$\mathrm{t}$} & \multirow[t]{2}{*}{ Sig. } \\
\hline & & B & Std. Error & & & \\
\hline \multirow{3}{*}{1} & (Constant) & .216 & .218 & & .989 & .326 \\
\hline & Process Design & .366 & .094 & .370 & 3.899 & .000 \\
\hline & Product Design & .544 & .098 & .528 & 5.559 & .000 \\
\hline
\end{tabular}

a. Dependent variable: production efficiency.

\section{Copyrights}

Copyright for this article is retained by the author(s), with first publication rights granted to the journal.

This is an open-access article distributed under the terms and conditions of the Creative Commons Attribution license (http://creativecommons.org/licenses/by/4.0/). 